Belo Horizonte, p. 1-358.

Disponivel em: http://www.letras.ufmg.br/poslit

\title{
Antônio Conselbeiro e Getúlio Vargas no Grande Sertão: Veredas? As fontes do autor e os caprichos da representaçã $0^{1}$ \\ Luiz Roncari I USP
}

Resumo: O objetivo deste estudo foi o de tentar desentranbar das representaçôes de duas das figuras mais singulares de nossa bistória, Antônio conselheiro e Getúlio Vargas, que tive a felicidade de encontrar e identificar num outro trabalho sobre o Grande Sertão: Veredas, a visão e o juizo de Guimarães Rosa sobre elas. Isto foi possivel apreender a partir das análises das significações que adquiriram no livro e da importância que tiveram para a definição do destino do berói Riobaldo, narrador do romance Grande sertão: veredas.

Palavras-chave: representação, literatura, história e política.

1. Trabalho apresentado no Colóquio Internacional Guimarães Rosa - 2006, UFRGS/UniRitter, no dia 10 de abril, no teatro Renascença, em Porto Alegre; na II Jornada de Estudos sobre Guimarães Rosa, UNESP, São José do Rio Preto, em 2 de maio de 2006; e no Seminário Internacional 50․ de Grande Sertão: Veredas, de Guimarães Rosa, SECMG/UFMG, em 24 de maio de 2006. 


\begin{abstract}
Acredito que a pesquisa deste ensaio, sobre a presença de Antônio Conselheiro e Getúlio Vargas no romance Grande Sertão: Veredas, nos ajudará a compreender melhor tanto a visão de mundo do autor, como a sua obra mestra. Neste sentido, todos os juízos de valor a respeito das duas personagens históricas e dos fatos correlatos a elas, que podem ser compreendidos aqui, só se referem à visão do romancista e não à do crítico. Pois o que nos interessa é melhor entender o pensamento e a ação artística de um grande autor e não as simpatias ou antipatias de um curioso, bisbilhoteiro das obras alheias.
\end{abstract}

$\mathrm{Na}$ abertura da Parte 3 do primeiro volume de meu livro, O Brasil de Rosa, num item que chamei de "O trapézio da travessia", eu disse que, do meu ponto de vista, o Grande Sertão tinha uma arquitetura que imitava a forma geométrica do trapézio (v. Roncari, 2004, p. 261). Em resumo e só para o que nos interessa aqui, eu afirmei que a sua primeira face, a da esquerda, a ascendente e que vai até o tribunal do julgamento de Zé Bebelo, ela nos mostrava os fatos relativos à formação do herói: as suas heranças maternas e paternas; o encontro com o menino no rio de-Janeiro; o encantamento produzido pela canção de Siruiz; a entrada para o bando de Zé Bebelo; as primeiras lutas; o conhecimento dos vários amores; o processo de identificação vivido durante o julgamento do antigo chefe; e, logo após, a tomada de consciência e o balanço de vida realizados no sertão aprazível, sem chefias nem lutas, na Guararavacã do Guaicuí. Os episódios que analisaremos agora estão na segunda face do trapézio, na da direita e descendente, que se inicia depois da notícia da morte por traição de Joca Ramiro e as lutas terríveis enfrentadas na fazenda dos Tucanos. Se a primeira face pode ser considerada como diurna ou clara, na medida em que nos relata os episódios formativos do herói e culmina com o grande ganho institucional e civilizatório do estabelecimento do tribunal no sertão, esta outra é mais noturna ou negra, por isso é descrita como uma descida "na inferneira". O seu único móvel é o da vingança e não o da justiça, como foi a anterior; ela se concentra agora no combate aos antigos aliados, o bando de Hermógenes e Ricardão, o que leva o herói ao apelo às forças extraordinárias para se superar e vencer os dois demônios que o moviam e o desafiavam: o ódio ao Hermógenes e o amor à Diadorim. 
Belo Horizonte, p. 1-358.

Disponivel em: http://www.letras.ufmg.br/poslit

\section{As atrações do regresso}

Os episódios desta segunda parte do livro já não são mais formativos, eles se apresentam como grandes obstáculos e desafios a serem enfrentados pelo herói e aos quais terá que reagir com a devida coragem (algumas vezes, com o medo paralisante) ou contando com a proteção das forças invocadas, para que o ajudem a definir o seu destino. Nesse percurso, o encontro de Riobaldo com Antônio Conselheiro e Getúlio Vargas significou para ele o confronto com dois apelos ou duas promessas simbólicas e paradigmáticas, com tendências e conteúdos opostos, aos quais, bem ou mal, o herói soube responder com o devido discernimento; para isto ele requeria mais do que a força adquirida com o pacto, ele carecia também da razão madura e da capacidade de escolha, fruto da formação. O que mais nos surpreende, analisando tais episódios, é verificar que o herói de certo modo se formou, que de alguma forma houve de fato formação, porém sempre dentro dos limites ideológicos e a partir da visão do autor, modernizante-conservadora e não revolucionária.

Com a figura de Antônio Conselheiro, Riobaldo se encontra logo após a travessia bem sucedida do Sussuarão e o aprisionamento da mulher do Hermógenes, que traz junto com o seu bando jagunço, integrado pelos catrumanos chefiados pelo Teofrásio. O significado para ele dessa passagem da travessia do Sussuarão, um tanto miraculosa e já por mim analisada, foi ele ter trocado de posição com Diadorim, quando passaram um para o lugar do outro, e culminou com o herói enfrentando à faca e esfolando o bruto jagunço Treciziano (v. Roncari, 2004, p. 236). Depois disso, na espera pelo recontro com o bando inimigo, numa certa altura, eles se defrontam com um velho, para quem o catrumano Teofrásio (a palavra de Deus) aponta a sua "garrucha antiqüíssima", mas que Riobaldo não permite que atire e, por isso, considera ter salvo a vida do pobre velho. Num segundo momento, é assim que o descreve:

Mas, no vir de cimas desse morro, do Tebá - quero dizer: Morro dos Ofícios - redescendo, demos com o velho, na porta da choupa dele mesmo. Homem no sistema de quase-doido, que falava no tempo do Bom Imperador. Baiano, barba de piassaba; goiano-baiano. O pobre, que não tinha as três espigas de milho em seu paiol. Meio sarará. A barba, de capinzal sujo; e os cabelos dele eram uma ventania (Rosa, 1963, p. 489). 
Em 14 de fevereiro de 1897, Machado de Assis publicou na revista A Semana uma crônica sobre a "celebridade" de Antônio Conselheiro. Ela fala de uma mulher simples que pedia ao vendedor de jornais uma folha que trazia o retrato do profeta. Esse retrato, na verdade, deve ter sido a ilustração caricata que Ângelo Agostini fez do Conselheiro para a revista D. Quixote de uns dias antes, de 13 desse mês, a qual o mostrava sendo adorado como um Messias pelos seus seguidores, e que hoje é reproduzida junto à crônica (v . Assis, 1973, p. 763). Na gravura, o Conselheiro aparece como uma figura raquítica, com um chapéu cônico, possivelmente para significar a sua loucura, usando a túnica característica, e com os cabelos e a barba como os do velho descrito no Grande Sertão. O que singulariza a ilustração de Ângelo Agostini é o fato de ele trazer, além do cajado de guia e pastor de homens na mão esquerda, também uma espingarda à bandoleira. A razão disso era a de confirmar o estigma e reafirmar o que todos diziam, de ele não ser um profeta qualquer, mas um profeta armado, "O fanático e bandido", como diz a legenda da revista. Fora isso, todos os retratos elaborados de Antônio Conselheiro seguem a mesma linha: a magreza, o rosto encovado, os cabelos esvoaçantes, as barbas espinhentas, a túnica ou samarra, o cajado, os olhos delirantes do iluminado ou enlouquecido. Euclides da Cunha cita a descrição que frei de Monte Marciano fez dele em seu relatório, depois da visita frustrada a Canudos:

Vestia túnica de azulão, tinha a cabeça descoberta e empunhava um bordão. Os cabelos crescidos sem nenhum trato, a caírem sobre os ombros; as longas barbas grisalhas mais para brancas; os olhos fundos raramente levantados para fitar alguém; o rosto comprido de uma palidez quase cadavérica; o porte grave e ar penitente (Cunha, 1985, p. 252).

Deve ter sido baseada nela a descrição que depois Euclides fez dele:

... E surgia na Bahia o anacoreta sombrio, cabelos crescidos até os ombros, barba inculta e longa; face escaveirada; olhar fulgurante; monstruoso, dentro de um hábito azul de brim americano; abordoado ao clássico bastão, em que se apóia o passo tardo dos peregrinos... (Cunha, 1985, p. 215 e 216).

Para ficarmos só nas representações feitas no tempo dos acontecimentos, a descrição realizada por Afonso Arinos, cujo livro, Os Jagunços, foi publicado em 1898, é mais detalhada e ficcionalizada, de modo a acentuar 
a dramaticidade da personagem, mas pouco muda com relação ao retrato sintético de Euclides, apesar de partir de um ponto de vista oposto. Para o escritor monarquista, nascido em Paracatu, extremo oeste de Minas, o sertão e o sertanejo não lhe eram estranhos nem desconhecidos, ao contrário, tanto quanto Paris, faziam parte da sua experiência e familiaridade. O seu sertão, como descrito nos festejos e congadas do início de Os Jagunços, compunha uma harmonia muito idealizada entre proprietários e empregados. Assim, para ele, o aparecimento de um profeta como o Conselheiro não era um fato estranho desafiante e ameaçador, antes fazia parte do pitoresco e da curiosidade do lugar:

A samarra de algodão encardido que vestia o corpo esquelético do enviado de Deus pareceu-lhe então a túnica dos santos; o rosto, extremamente pálido, os cabelos e as barbas crescidas eram tais quais os da imagem de São Francisco das Chagas, que o camarada vira na matriz de sua terra, ajoelhada e de braços abertos aos pés da imagem do Senhor Crucificado. [...]

A idade não lhe vencera a indômita energia do corpo frágil, nem lhe deixara na fisionomia os avisos da Natureza ao homem, para que se apreste a pagar-lhe o tributo derradeiro. Os cabelos não se lhe branquearam; conservam-se grisalhos como dantes. Os olhos, porém, parece adquiram mais fogo e o olhar mais amplitude. Vendo já meio realizado o seu sonho, o olhar do missionário não penetra somente no íntimo dos corações; rasga a vastidão do espaço, vence a carreira do tempo e tenta surpreender o segredo do futuro (Arinos, 1985, p. 118 e 119). ${ }^{2}$

No velho encontrado por Riobaldo, o que destoava desses retratos é que ele não portava um cajado e uma arma, como na gravura de Ângelo Agostini, mas uma arma arcaica que poderia servir-lhe também de cajado. É essa

2. As descrições que Robert B. Cunninghame Graham faz dele são um tanto contraditórias, mas não se distinguem do modelo comum. Numa, ele não portava chapéu: "Não usava chapéu e seus cabelos longos caíam sobre seus ombros. Sua barba era hirsuta e se espalhava sobre seu peito, lisa e bíblica. Sua roupa era uma túnica longa de fio rústico azul e se apoiava sobre o clássico cajado dos peregrinos, nodoso e torcido, mas lustroso pelo uso prolongado" (2002, p. 89). Mas logo a seguir ele se desdiz: "Sua longa túnica azul sem cinto fazia-o parecer ainda mais magro do que era e mais macilento. Seu chapéu de peregrino, que usava geralmente pendurado sobre os ombros, à moda de um pastor de Tessália na época clássica, as sandálias que calçava e seus olhos muito abertos de olhar intenso davam-lhe o aspecto como de um messias louco do tipo oriental" (2002, p. 90 e 91). 
a sua característica maior, pois tudo nele é arcaico e lembra o passado ou, em outros termos, é ultrapassado. Este aspecto é enfatizado, primeiro, quando Riobaldo se refere aos seus saberes, logo depois de descrever a sua aparência física:

Perguntei uma coisa, que ele não caprichou entender, e o catrumano Teofrásio, que já queria se mostrar jagunço decisivo, o catrumano Teofrásio bramou - abocou a garruchona em seus peitos dele. Mas, que não deu tujo. Esse era o velho da paciência. Paciência de velho tem muito valor. Comigo conversou. Com tudo que, em tão dilatado viver, ele tinha aprendido. Deus pai, como aquele homem sabia todas as coisas práticas da labuta, da lavoura e do mato, de tanto tudo. Mas, agora, que tanto aforrava de saber, o derrengue da velhice tirava dele toda possança de trabalhar; e mesmo o que tinha aprendido ficava fora dos costumes de usos. Velhinho que apertava muito os olhos (Rosa, 1963, p. 489, grifo meu).

E depois, quando descreve as suas armas, igualmente ultrapassadas:

Seria velhacal? Não fio. E isto, que retrato, é devido à estúrdia opinião que divulgou em mim esse velho homem. Que, por armas de sua personalidade, só possuía ali era uma faquinha e um facão cego, e um calaboca-porrete esse que em parte era ocado e recheio de chumbo, por valer até para mortes. E ele mancava: por tanto que a metade do pé esquerdo faltava, cortado - produção por picada de cobra - urutu geladora, se supõe. Animado comigo, em fim me pediu um punhado de sal grande regular, e aceitou um naco de carne-de-sol. Porque, no comer comum, ele aproveitava era qualquer calango sinimbú, ou gambás, que, jogando neles certeiramente o calaboca, sempre conseguia de caçar. Me chamou de: - "Chefão cangaceiro..." (Rosa, 1963, p. 489, grifos meus).

O arcaísmo das armas dos combatentes de Canudos é um fato ressaltado por todos os testemunhos. Aqui, o interessante a ser analisado é a forma de apresentação do porrete do Conselheiro, pois nela Guimarães se utiliza de duas fontes distintas: Euclides da Cunha e Afonso Arinos. É o primeiro que se refere a esse tipo de arma entre os jagunços, ao enumerá-las, e ressaltando não só o seu arcaísmo, mas também como indicativas do estágio retrógrado dos mesmos: 
Belo Horizonte, p. 1-358.

Disponivel em: http://www.letras.ufmg.br/poslit

Por fim as armas - a mesma revivescência de estádios remotos: o facão jacaré, de folha larga e forte; a parnaíba dos cangaceiros, longa como uma espada; o ferrão ou guiada, de três metros de comprido, sem a elegância das lanças, reproduzindo os piques antigos; os cacetes ocos e cheios pela metade de chumbo, pesados como montantes; as bestas e as espingardas (Cunha, 1985, p. 233, último grifo meu).

Porém, o nome da arma, de "calaboca", foi dado por Afonso Arinos, ao falar também do seu arcaísmo:

Os jagunços quase não perdiam tiros, mas as armas eram todas de carregar pela boca e de pequeno alcance. Caboclos havia que tinham ainda muita fé nos trabucos, bacamartes, clavinotes, cala-bocas antigos. Esses parceiros não queriam saber de outras armas. Até espingardas pedreiras apareciam nas mãos de alguns, que juravam ser tais as armas de fiança (Arinos, 1985, p. 162 e 163, grifo meu).

O que torna mais evidente a amplitude das fontes de Guimarães, que não se resume à Euclides e nem é ele a mais importante nesta representação direta de Antônio Conselheiro, a qual simboliza no romance o conjunto das experiências de Canudos, como veremos, está nesta frase um tanto enigmática, citada mais acima: "Mas, no vir de cimas desse morro, do Tebá - quero dizer: Morro dos Ofícios”. Euclides, quando se refere à povoação do Belo Monte, a chama, pelo menos por duas vezes, de "a Tróia de taipa dos jagunços" (Cunha, 1985, p. 169 e 231, grifo meu). Porém, quem, ao falar do profeta e dos fatos de Canudos, se refere à Tebas e à Tebaida, é Afonso Arinos, quando diz ser Antônio Conselheiro "como os cenobitas da Tebaida" (Arinos, 1985, p. 133, grifo meu). Posteriormente, Robert B. Cunninghame Graham, que no seu livro transcreve trechos extensos de Os Sertões, mas não cita Afonso Arinos entre as suas fontes, por duas vezes, compara também o Conselheiro a "um monge da Tebaida" (Graham, 2002, p. 89 e 121). A auto-correção feita pelo narrador Riobaldo mais acima, "do Tebá - quero dizer: Morro dos Ofícios", associa a cidade de Canudos não a um covil de bandidos dados a licenciosidade, como faz Euclides, quando diz: "Canudos era o homizio de famigerados facínoras" (Cunha, 1985, p. 239), mas a um lugar caracterizado pelo exercício pacífico das funções do trabalho. E é Afonso Arinos que nos dá a melhor imagem da operosidade dos moradores de Belo Monte, ele que nascera, vivera e conhecia muito bem o sertão: 
A verdade é que, nem Taracatu, nem Simão Dias, nem Geremoabo, nem Monte Santo, nenhuma das cidadezinhas do sertão, ao norte, ao sul, ou à beira do São Francisco, era tão movimentada, tão trabalhadora e tão morigerada como Belo Monte, que o povo de fora chamava Canudos. A autoridade do Conselheiro era ampla e indiscutível; sua influência, tão profunda quanto o sentimento religioso que ele encarnava. [...]

Sua influência se estendia num raio vastíssimo de sertão, abrangendo terras de muitos Estados; e essa influência era benéfica, porque nenhum outro poder humano conseguiria, como ele, domar aquele povo bravio, fazer dele um grande instrumento de disciplina, extirpando-lhe ao mesmo tempo as manifestações de banditismo. Aquela gente não sabia o que era roubo. A maioria das casas não tinha, por assim dizer, portas nem fechaduras. E naquele povo todo reinava a abastança, filha do trabalho. Eles não conheciam o luxo, nem o que se chama erroneamente "conforto", aí pelas cidades grandes. Criavam seu gado, tinham os paióis sortidos e as roças plantadas, mas dormiam indistintamente em catres sofríveis, em jiraus, por cima de um couro na terra dura, sob a proteção de um teto, ou, então, ao relento. Não tinham horas nem refeições certas. Se o serviço lhes tomasse o tempo, alguma vaquejada, ou campeação difícil lhes ocupasse o dia, varavam indiferentemente de sol a sol, sem comer (Arinos, 1985, p. 165 e 166; v.tb. as cenas seguintes das p. 128).

A referência à Tebas, seja à de fonte cristã, o refúgio de cenobitas e eremitas no Egito, nos inícios da nova crença, como à bíblica e à grecoromana, só vem confirmar os temas centrais dos episódios de Canudos. No Velho Testamento, Tebas ou No-Amon (Jeremias, 46, 25; Ezequiel, 30, 14-16; e Nahum, 3,8$)$ aparece como a cidade condenada a ser devastada pela cólera de Jeová. E a epopéia latina, Tebaida, de Estácio, narra o cerco da cidade de Tebas e a luta fraticida pelo poder entre os dois filhos de Édipo, Polinices e Eteócles, como foi o massacre de brasileiros por brasileiros em Canudos. As duas últimas fontes se referem ao destino funesto da cidade.

Uma série de outras referências nos induz a tomar "o velho" pelo Antônio Conselheiro, como quando "falava no tempo do Bom Imperador", que poderia ser tanto D. Pedro II, como o rei Saturno da Idade de Ouro. Sabemos hoje quanto eram controvertidas as afinidades do profeta do Belo Monte com o Império, assim como as acusações que faziam a respeito disso para justificar o combate e depois o massacre. Também, por duas vezes, a narrativa repisa o lado conselheiro do velho, nesta passagem, importante também por outras razões: 
Belo Horizonte, p. 1-358.

Disponivel em: http://www.letras.ufmg.br/poslit

Acabando que, para me render benefício de agradecimento, ele me indicou, muito conselhante, que, num certo resto de tapera, de fazenda, sabia seguro de um dinheirão enterrado fundo, quantia desproposital. Eu fosse lá... - ele disse -; eu escavasse tal fortuna, que merecida, para meus companheiros e para mim... - "Aonde, rumo?" - indaguei, por comprazer. Ele piscou para o mato. Por lá, trinta e cinco léguas, num Riacho-das-Almas... Toleima. Eu ia navegar assim para acolá, passar matos, furar a caatinga por batoqueiras, por louvar loucura alheia? Minha guerra nem não me dava tempo. E, mesmo, se ele sabia assim, e verdade fosse, por que era que não ia, muito pessoalmente, cavacar o ouro para si? Derri dele, brando. Por que é que se dá conselho aos outros? Galinhas gostam de poeira de areia - suas asas... E o velho homem - cujo. Ele entendia de meus dissabores? Eu mesmo era de empréstimo. Demos o demo... E possuía era meu caminho, nos peitos de meu cavalo. Siruiz. Aleluia só (Rosa, 1963, p. 489 e 490, grifos meus).

A importância da passagem está, por um lado, na crítica explícita ao tipo de conselho dado pelo velho: a promessa de mundos e fundos a serem conseguidos facilmente, com a do tesouro enterrado. Ela reproduzia a fantasia do eldorado, que marcara a conduta do homem do país desde a colonização e era tema corrente nas interpretações do Brasil e na própria obra de Guimarães Rosa. Para Riobaldo, aquilo era um puro engano, assim, ele vê o velho como um "cujo" que planta e promete ilusões. E, por outro, o rumo que aponta é o do mar, o de Leste, como quando o Conselheiro prometia que “...Em 1896 hade rebanhos mil correr da praia para o certão; então o certão virará praia e a praia virará certão" (Escrito copiado por Euclides da Cunha dos cadernos encontrados em Canudos: 1985, p. 223). Ficamos sabendo que o rumo era o de Leste porque, o herói, ao recusar-se a acreditar naquelas promessas, comanda o seu bando para Oeste, para os lados de um sertão mais fundo do que aquele em que estavam: "fomos, tocamos, querendo o poente e tateando tudo" (Rosa, 1963, p. 491, grifo meu). A determinação é importante, pois, a seguir a ilusão da riqueza fácil prometida, "Eu ia navegar assim para acolá, passar matos, furar caatinga por batoqueiras, por louvar loucura alheia?", ele escolhe continuar a sua luta, "Minha guerra não me dava tempo". A sua atitude é oposta às de João Miramar e Serafim Ponte Grande, dos romances de Oswald de Andrade, os quais, do litoral que imitava a civilização européia, só tinham as vistas para ela própria e as suas utopias. Riobaldo se volta para o interior, para o sertão, ele quer enfrentar os seus demônios, e não buscar uma civilização já 
estabelecida, mas para a qual pouco havia contribuído. ${ }^{3}$ Só posteriormente o herói percebe como esse encontro e a sua decisão tinham sido importantes; ele reconhece que ali também o seu destino estava em jogo, pois, no rumo e caminho que lhe apontava o velho estava Nhorinhá, a prostitutazinha promíscua e bela, do amor baixo e fácil, porém desintegrador e sem muita promessa de futuro, como podem testemunhar os dramas internos e externos vividos por Soropita. Este foi um jagunço amansado que se casou com uma prostituta, Doralda, não porque gostasse dela apesar de seu passado, mas porque ela era uma a rainha entre as prostitutas ou a melhor de todas. Com isso, ele se condena à agonia de querer ter uma santa em casa, a dama da noite convertida em mulher fiel, mas que continuasse amando como uma prostituta. Ela, muito mais do que ele, consegue conviver com essa duplicidade de papéis (v. "O cão do sertão no arraial do Ão", in Roncari, 2006). Devido a isso a escolha de Riobaldo foi a mais importante, pois, se tivesse ouvido o conselho do velho, teria feito o caminho para um outro engano, "como o belo do azul", segundo suas palavras, quando compara o que poderia ter sido com o que no momento ele era, fazendeiro assentado e bem casado com Otacília:

Do que hoje sei, tiro passadas valias? Eh - fome de bacurau é noitezinha... Porque: o tesouro do velho era minha razão. Tivesse querido ir lá ver, nesse Riacho-das-Almas, em trinta e cinco léguas - e o caminho passava pelo São

3. Para contrastarmos com essa volta para fora e a atração pelo externo, dominante na época e forte ainda hoje, vale aqui mencionar alguns testemunhos sobre a atenção e a ação política de Getúlio Vargas dirigidas para o interior: Antônio Balbino, ministro da Educação do segundo governo Vargas: "Ele [Getúlio Vargas] me dizia: 'Você já imaginou o que será este país quando a gente puder interiorizar a educação e o trabalho?"; Segadas Viana, fundador do PTB e ministro do Trabalho do segundo governo Vargas: "Ele gostava do Brasil realmente. O Marcondes disse muito bem uma vez: 'O Getúlio era um homem que governava de costas para o Atlântico'. Ele olhava era para o interior.”; Pedro Ludovico, fundador do PSD e governador de Goiás: "Ele achava que o Brasil devia crescer para o oeste porque o litoral já estava mais ou menos povoado, mais ou menos industrializado. A marcha para o oeste seria o futuro do Brasil. Ele foi o primeiro presidente da República a pisar o solo goiano.”; Nero Moura, ministro da Aeronáutica do segundo governo Vargas: "O presidente tinha vontade de empurrar o país para dentro do território, sair das praias. Em maio de 54 nós fomos inaugurar o aeroporto de Manaus. [...] Saímos de noite, para amanhecer em Cachimbo, que é uma serra lá no sul do Pará. [...] Lá ele viu a floresta Amazônica. Ficou encantado com aquilo, achou uma coisa espetacular. Para aquela área ninguém nunca tinha ido. Só o pessoal da FAB e índio" (Lima, 1986, p. 247 e 248). 
Belo Horizonte, p. 1-358.

Disponivel em: http://www.letras.ufmg.br/poslit

Josezinho da Serra, onde assistia Nhorinhá, lugarejo ditoso. Segunda vez com Nhorinhá, sabível sei, então minha vida virava por entre outros morros, seguindo para diverso desemboque. Sinto que sei. Eu havia de me casar feliz com Nhorinhá, como o belo do azul; vir aquém-de. Maiores vezes, ainda fico pensando. Em certo momento, se o caminho demudasse - se o que aconteceu não tivesse acontecido? Como havia de ter sido de ser? Memórias que não me dão fundamento. O passado - é ossos em redor de ninho de coruja... E, do que digo, o senhor não me mal creia: que eu estou bem casado de matrimônio - amizade de afeto por minha bondosa mulher, em mim é ouro torqueado. Mas - se eu tivesse permanecido no São Josezinho, e deixado por feliz a chefia em que eu era o Urutu-Branco, quantas coisas terríveis o vento-das-nuvens havia de desmanchar, para não sucederem? Possível o que é - possível o que foi. O sertão não chama ninguém às claras; mais, porém, se esconde e acena. Mas o sertão de repente se estremece, debaixo da gente... E - mesmo - possível o que não foi. O senhor talvez não acha? Mas, e o que eu estava dizendo, mas mesmo pensando em Nhorinhá, por causa. Dói sempre na gente, alguma vez, todo amor achável, que algum dia se desprezou... Mas, como jagunços, que se era, a gente rompeu adiante, com bons cavalos novos para retroco. Sobre os gerais planos de areia, cheios de nada. Sobre o pardo, nas areias que morreram, sem serras de quebra-vento (Rosa, 1963, p. 491).

O mesmo homem que tinha apelado às forças extraordinárias e procurado o pacto com o diabo (se o fez ou não, é outra história), agora havia escolhido por vontade própria e evitado os dois enganos, inclusive aquele do "belo do azul", como ele erroneamente imaginava: "Eu havia de me casar feliz com Nhorinhá". E ele encontra uma justificativa muito razoável para não acreditar naquelas promessas miraculosas do velho, quando diz: "E, mesmo, se ele sabia assim, e verdade fosse, por que era que não ia, muito pessoalmente, cavacar o ouro para si?" (Rosa, 1963, p. 490). Porém, quem o tinha alertado era o próprio velho, que havia the dito algo importante sobre o sertão, quando o herói lhe perguntou se ele era nascido ali ou em outro lugar e se ele achava mesmo "assim que o sertão é bom?...". O velho, no mesmo modo delirante dos profetas gnósticos, como tanto Euclides quanto Robert B. C. Graham gostavam de associá-lo, lhe responde com palavras que Riobaldo "não decifrava", ao mesmo tempo em que lhe apontava o dedo como se fosse uma faca no peito: "- 'Sertão não é malino nem caridoso, mano oh mano!: - ...ele tira ou dá, ou agrada ou amarga, ao senhor, conforme o senhor mesmo."” 
O eixo e a roda: $v .12,2006$

Disponível em: bttp://www.letras.ufmg.br/poslit

(Rosa, 1963, p. 490). Apesar da aparência paradoxal das palavras do velho, que afirmam os contrários, dizendo e desdizendo ao mesmo tempo, elas tinham sabedoria, pois elas poderiam dizer que não era o sertão que fazia os homens, ele era neutro, poderia ser tanto uma coisa como outra, o de Afonso Arinos ou o de Euclides da Cunha, mas eram os homens, cada um, inclusive o herói, que faziam o sertão. Aqui, ao contrário das sociedades modernas, a determinação não era do meio sobre os homens, mas destes sobre o meio, pois tudo estava ainda por se fazer. Creio não ser por acaso que a outra figura paradigmática que Riobaldo encontra, em tudo oposta ao velho, seja a de um sujeito político por excelência (e não a de um economista, lembrando a etimologia do termo), Getúlio Vargas. A escolha do herói, portanto, de recusar as promessas e os enganos para os quais apontava o velho, era correta, na medida em que ele negava a volta ao passado e à tradição costumeira, ou pelo menos aos erros que eles implicavam. O que significava não apenas recusa, mas também um aprendizado ou uma decifração, ainda que um tanto intuitiva, como era do conhecimento gnóstico, como a sabedoria do velho. Como vimos deste o início, nas primeiras observações sobre ele, que não era desprovido de conhecimento, ao contrário, "como aquele homem sabia todas as coisas práticas da labuta", só que aquele saber estava então "fora dos costumes de usos". A bela imagem enigmática de Riobaldo, usada para simbolizar o passado, "O passado - é ossos em redor de ninho de coruja..." (Rosa, 1963, p. 491), poderia significar justamente aquele saber arruinado do velho, os ossos de um cadáver

que circundava a ave de Minerva, como um conhecimento carcomido pelo poder corrosivo do tempo, com o qual ele não queria pactuar. O que, de outro modo, e segundo afirmamos acima, que a representação aqui de Antônio Conselheiro simbolizava o conjunto da experiência de Canudos e o seu significado na história do país, parece nos dizer que ela era uma experiência regressiva, portanto, a não ser imitada, pois outros encontros viriam e mais prenhes de futuro.

\section{As promessas de futuro}

Riobaldo, depois das batalhas do Tamanduá-tão e do Paredão, e da morte dos seus demônios guerreiros, Ricardão e Hermógenes, e amoroso, Diadorim, foi acometido de uma forte febre purgativa, febre-tifo, "Terçã", "trelada com sezão". Ele que pensava estar nas Veredas-Mortas, mais tarde, pelo compadre Quelemém, fica sabendo que estava na verdade era nas Veredas- 
Altas. Acreditava também que os homens que haviam sobrado do seu bando o tinham levado para "dentro duma casa muito pobre". Lá ele teve um delírio muito significativo, de um fazendeiro maligno tomado pelo demônio, cuja posse se manifestava como uma febre que o queimava internamente e o fazia uivar, e ele pedia aos escravos que jogassem baldes de água fria sobre o seu corpo para aliviá-lo do calorão e ele não viesse mesmo a pegar fogo. Era de certo modo um delírio especular, que refletia a sua própria situação ou o modo como ele interpretava a sua febre e queimação. Porém, esta, ao contrário da do fazendeiro maldoso, vinha salvá-lo e não perdê-lo, por isso ela era purgativa ou regenerativa. Ela matava algo de ruim que vigorava ainda nele, como se limpasse o terreno das ervas daninhas, a sua alma selvagem, para que frutificasse ali as plantas domesticadas. Disso nos daremos conta nos episódios que se seguem, depois que sarou e voltou a si, e percebeu que também não estava mais no asilo da casinha pobre, mas na casa-grande de uma grande fazenda, para onde o tinham levado. Ali, ele se viu inteiramente amparado e protegido, sob a boa guarita de um velho fazendeiro, seo Ornelas. São importantes as descrições tanto do lugar, a fazenda Barbaranha, quanto do fazendeiro, porque elas procuram mostrar como nessas Veredas Altas ele já não estava mais no sertão nem entre jagunços, mas num lugar ameno e de trato civil. Os seus primeiros bons sentimentos são os de quem havia saído de um tempo mítico e entrado no da história, o que lhe provocava satisfação, e disso ele se deu conta ao notar na parede da casa-grande "a marca dos tempos, numa folhinha de parede", embora se sentisse ainda sem alma, "um saco cheio de pedras". A fazenda era um lugar de delicadezas, "caldo de galinha" e "lençóis alvos", e feminino, "Todos, a senhora dele, as filhas, as parentas", e o louvavam não pela sua nomeada como jagunço valente, tomando a sua luta como uma coisa pessoal, mas pelo sentido geral da sua ação guerreira, no fundo, pacificadora e civil, e em benefício de todos: "eu tivesse vindo, corajoso, para derrubar o Hermógenes e limpar estes Gerais da jagunçagem”. O interessante é que esse fato, aqui atribuído a Riobaldo, fazia parte, na verdade, dos "programas nacionais" de Getúlio, de atribuir à União, ao Estado central, tanto dar combate à seca e à malária, como ao jaguncismo das margens do São Francisco e ao cangaço dos sertões do nordeste (V. sobre o assunto o meu estudo aqui já referido, "O cão do sertão no arraial do Ão"): 
meio longe aquele pesar, que me quebrantava. Lembro de todos, do dia, da hora. A primeira coisa que eu queria ver, e que me deu prazer, foi a marca dos tempos, numa folbinha de parede. Sosseguei de meu ser. Era feito eu me esperasse debaixo de uma árvore tão fresca. Só que uma coisa, $a$ alguma coisa, faltava em mim. Eu estava um saco cheio de pedras.

Mas aquele seo Ornelas era homem de muita bondade, muita honra. Ele me tratou com categoria, fui príncipe naquela casa. Todos - a senhora dele, as filhas, as parentas - me cuidavam. Mas o que mormente me fortaleceu, foi o repetido saber que eles pelo sincero me prezavam, como talentoso homemde-bem, e louvavam meus feitos: eu tivesse vindo, corajoso, para derrubar o Hermógenes e limpar estes Gerais da jagunçagem. Fui indo melhor (Rosa, 1963, p. 566 e 567 , grifos meus).

Não era a primeira vez que Riobaldo passava por aquele lugar, pela fazenda Barbaranha, de seo Ornelas. Ambos já eram seus conhecidos. Depois da tentativa do pacto, de assumir a chefia do bando e compô-lo com os catrumanos, tendo à mão direita o cego Borromeu e à esquerda o pretinho Guirigó, e o Teofrásio no seu jegue, ele se sente seguro e se afirma como jagunço bravo, chefe daquela armada de estropiados um tanto carnavalesca. Esta passagem deve ser lida como se fosse o urro gutural de um bicho, com as palavras raspando na garganta:

Ah, não, eu bem que tinha nascido para jagunço. Aquilo - para mim - que se passou: e ainda hoje é forte, como por um futuro meu. Eu estou galhardo. Naquilo, eu tinha amanhecido. Comi carne de onça? Esquipando, eu queria que a gente entrasse, daquele jeito, era em alguma grande verdadeira cidade (Rosa, 1963, p. 424, grifo meu).

Porém, onde ele entra, é numa grande fazenda, cujos moradores e costumes "cordiais", o obrigam a uma primeira metamorfose - desta vez ainda momentânea, pois ele está em missão de guerra -, que nega inteiramente a ferocidade jagunça da qual havia se vangloriado anteriormente, aquela de quem comeu "carne de onça". Porém não é só isso que acontece, a mudança não é unilateral; esses mesmos moradores da fazenda são obrigados também a assimilarem aqueles elementos novos e estranhos do bando de Riobaldo, de modo a integrá-los nas suas cortesias. Com isso se cria no lugar, como uma primeira experiência de laboratório, uma nova harmonia, onde uns são obrigados a adquirirem os freios das relações civis e corteses, e outros a conviverem com os que vinham debaixo e do sertão bravio. E tudo se passa sob a regência 
de seo Ornelas. Esse processo altamente integrador e pacificador, com um aprendendo com o outro, é descrito como um processo político-social e carregado de índices que nos apontam para um momento histórico da vida brasileira: o período no qual Getúlio Vargas, identificado aqui como uma figura símbolo e dotada de uma política, esteve à frente do poder. Valeria a pena ler toda a passagem, mas, como ela é muito longa, irei resumir apenas as suas referências mais significativas e analisá-las. O nome do fazendeiro é Josafá Jumiro Ornelas, no qual ressoa o sobrenome materno de Getúlio Dornelles Vargas, e nós veremos como o peso e o significado do feminino no lugar é bem maior do que no sertão bravio; o nome da fazenda é Barbaranha, o qual nos lembra o de Oswaldo Aranha, líder político gaúcho que acompanhou do começo ao fim a trajetória política de Getúlio. O nome da fazenda "Barbaranha" deve ter sido pensado no sentido de recordar como o ideário de Oswaldo Aranha se radicava no civilista de Rui Barbosa, Barb+aranha, em oposição ao militarista de Pinheiro Machado e Hermes da Fonseca, representados no Grande Sertão como Ricardão e Hermógenes. ${ }^{4}$ Essa história subterrânea que sustenta o romance, embora não o esgote nem o resuma, com o risco de transformá-lo numa simples alegoria, pois é apenas uma das camadas de composição do texto, não pode entretanto ser desconsiderada, se quisermos reconhecer os valores que nele são afirmados ou negados. Além de nos

4. Quem observa a relação entre o ideário de Oswaldo Aranha e o de Rui Barbosa é Aspásia Camargo, no ótimo ensaio biográfico que escreveu sobre a "trajetória política" do primeiro: "A presença de Oswaldo aquece os comícios e as manifestações contra Hermes, organizados no Largo de S. Francisco, sob a influência de Rubens Maciel e da oposição gaúcha representada pelo Grupo Gaspar Martins. Por trás de tudo pairavam as idéias de Rui Barbosa, que concorrera, em vão, contra Hermes da Fonseca em 1910, mas que deixara como saldo uma Oração aos moços e um grave libelo contra a República Velha que iria repercutir em cadeias sucessivas de protesto até sua queda final, em 1930. O eterno derrotado Rui acabou, afinal, moralmente vitorioso. Tornou-se símbolo da luta pela purificação dos costumes políticos e da renovação jurídico-institucional, apregoada através da proposta da revisão da Constituição de 1891. [...]/ A chama de Rui permaneceu muito viva no coração de Oswaldo e em seus compromissos políticos que se confundem com a UDN na derrocada de Vargas, em 1945. Prefaciando o livro sobre Rui Barbosa em inglês, 30 anos mais tarde, ele não esconde sua admiração pelo mesmo, que o castilhismo não conseguira reprimir." E, um pouco mais adiante, diz: "Rui Barbosa e Pinheiro Machado foram, em sua época, a encarnação de duas grandes linhagens que disputavam ideologicamente o controle do sistema republicano, ramificando-se nos estados, através da elite intelectual que ocupava os jornais e as tribunas políticas" (Camargo, 1996, p. 42). 
escapar outros conteúdos de que trata, mesmo que secundários ou extraliterários, mas se não vislumbrados, pode isso comprometer a nossa compreensão do que de fato o autor está falando, assim como os seus juízos éticos e cognitivos. O pior que pode acontecer quando passamos por cima da história e desconsideramos o âmbito das preocupações do autor é ou o rebaixarmos ou o usarmos para dizer o que gostaríamos que dissesse.

São conhecidas de todos as afinidades e as diferenças entre Getúlio Vargas e Oswaldo Aranha, mas como duas oposições conciliatórias e complementares. Quem registrou com muita acuidade esse fato foi o amigo e chefe de Guimarães Rosa, o Ministro das Relações Exteriores dos governos Dutra e Getúlio Vargas, João Neves da Fontoura, nas suas Memórias, uma das melhores da nossa vida republicana. Vale a pena acompanhar o paralelo que ele faz:

Os temperamentos de Vargas e Aranha contrastavam por completo. Talvez por isso se houvessem entendido no meio de suas separações, reservas e profundas desarmonias, como acontece comumente em certos casais. $\mathrm{Na}$ política, como no amor, não raro se processa o acordo dos contrários.

Aranha - homem-multidão - vivia sempre cercado, a casa cheia, falando sem cessar. Os amigos, acampados dia e noite em volta dele, constituíam, embevecidos, sua permanente platéia.

Vargas, ao oposto, apesar de comunicativo, muito atraente no trato pessoal, acolhedor, de uma grande simpatia física, gracioso nas palavras, era um individualista fechado no seu eu. Não se abria com ninguém. Chegou mesmo a dizer que preferia ser interpretado a interpretar-se. Fazia-se forte nos seus silêncios, nas reticências, nas meias palavras, sem embargo de ser orador brilhante nos improvisos.

Aranha dava-se por inteiro. Vargas mantinha indevassáveis seus territórios íntimos mesmo para os amigos. Ao homem, que não faz confidências, sobra facilidade para recuar ou avançar na forma que lhe for ditada pelas conveniências da sua política.

5. Essa idéia de um vínculo quase matrimonial no plano político-ideológico com Oswaldo Aranha, dado em grande parte pelo "castilhismo" de ambos, estava inclusive na cabeça de Getúlio. É assim que se refere ao amigo, no seu Diário, dos dias 1‥ a 3 de março de 1932: "Retirando-se este [Maurício Cardoso] recebo a visita de Osvaldo Aranha, emocionado, abatido e revoltado. Um temperamento complexo, vário, tempestuoso e apaixonado, mas sincero, mesmo nas suas infidelidades intelectuais”. (Vargas, 1995, p. 93) Aspásia Camargo usa a seguinte expressão para caracterizar a relação havida entre os dois: "complementaridade na diferença" (Camargo, 1996, p. 21). 
Em resumo: ao redor de Aranha lavrava um círculo de fogo, dardejando ação, incêndio que ele mesmo às vezes não conseguia ou não sabia apagar. Vargas protegia seu isolamento interior por uma couraça de gelo e pelo senso da medida na convivência com os semelhantes (Fontoura, 1963, p. 9).

Os dois volumes dessas Memórias, "Borges de Medeiros e seu tempo" e "A Aliança Liberal e a Revolução de 30", foram amplamente citados e elogiados por Guimarães Rosa no seu discurso de posse, na Academia Brasileira de Letras, na vaga deixada justamente pelo amigo. Para ele havia um outro membro importante que compunha uma espécie de "tríade" de poder de influência político-ideológica no tempo, que era o próprio memorialista. João Neves foi uma pessoa muito próxima a Guimarães, de quem o escritor foi subordinado e chefe de gabinete, e foi nesse discurso de estilo arrevesado, como modo de cifrar para mais esconder do que revelar, e que hoje soa como afetação desnecessária, ele discorreu explicitamente sobre as suas afinidades e simpatias com relação aos homens e fatos políticos do período. Citá-lo aqui acredito ser importante para podermos contrastar e ver como correspondem ao sentido das representações do romance.

Então - e ele e Vargas? E ante Aranha? A dúvida pertine e o ponto pertence, cortando aqui desconversa, porquanto dentre bando e numeroso escol - os brasileiros grandes do Rio Grande - plano adiante inscritos na mesma moldura: tríade que em conjunto giro insólito a história nos trouxe. Impede, a pergunta. Resposta, Deus sabe, só sou contador. Vínhamos, por exemplo, de visitar Oswaldo Aranha - feérico de talento, brilho, genialidade, uai, e daquele total conseguido esculpir-se em ser - e Neves pauteou: "Você estava extasiado, empolgado..." Mas vi e já advertira em que não menos cedia ele à cordial fascinação. - "Sagarana (sic sempre), cuida disto para o João..." - telefonava-me Aranha alguma vez. Prezavam-se e queriam-se, alta, gauchamente; a despeito de quais-que despiques, queixas, rixas, uniaos a verdade da amizade. Getúlio Vargas, muito falávamos a seu respeito, compondo uma nossa tese de controvérsia. Meu interesse, sincero, pela imensa e imedida individualidade de Vargas, motivava-se também no querer achar, em sã hipótese, se era por dom congênito, ou de maneira adquirida mediante estudo e adestramento, que ele praticava o wu wei - "não interferência”, a norma da fecunda inação e repassado não-esforço de intuição - passivo agente a servir-se das excessivas forças em torno e delas recebendo tudo pois "por acréscimo". - "Enigma nenbum, apenas um fatalista de sorte..." - encurtava João Neves, experimentando fácil dissuadir- 
me. Mas, apto ele mesmo ao mistério, sensível às cósmicas correntes, à anima mundi antiga, teria de hesitar, de vez em quase, também a memória cobradora beliscando-o. - "De fato, o Getúlio dá estranhezas, nunca ofegou ou tiritou, nem se lastimava de frio ou calor, que nós outros todos padecíamos, nada parecia mortificá-lo..." - concedia-me, assim pequenas observações. Logo, porém, sacudia-se daquilo. Fazia pouco de minha admiração-e-simpatia por Vargas, sem com ela agastar-se (Rosa, 1983, p. 443 e 444, o negrito é meu).

Do mesmo modo como foi tomado o gesto simbólico dos gaúchos, quando amarraram os cavalos no obelisco da Avenida Rio Branco, ao chegarem ao Rio de Janeiro, vitoriosos na Revolução de 30, e imporem o novo ideário ao país, foi com um gesto equivalente que o jagunço Riobaldo e o seu bando penetraram na fazenda Barbaranha. Isto se passou três dias depois da festa de São João e nas vésperas da de São Pedro, como diz o herói: "No mastro, que era arvorado para honra de bandeira do santo, eu amarrei o cabresto do meu cavalo" (Rosa, 1963, p. 426). Esse ato simbólico de Riobaldo na fazenda Barbaranha, equivale ao que se passou no período dos governos de Getúlio Vargas. Foi nesse tempo que o país e o Estado acordaram e tiveram que se preocupar com as questões sociais e trabalhistas. Pela ação também das camadas trabalhadoras, tiveram que tratá-las não mais como "caso de polícia", ao modo de Washington Luís, de cuja prepotência e autoritarismo as Memórias citadas dão um testemunho muito bem fundamentado, e, com isso, buscar formas de reconhecer o trabalhador como um novo sujeito histórico e integrá-lo no processo político. Ainda que isso se desse em alguns momentos, como durante o Estado Novo, com a substituição do autoritarismo civil apoiado no domínio agrário e comercial pelo autoritarismo carismático tutelado pelo poder militar, principalmente o dos antigos tenentes. ${ }^{6}$ Aqui também, na ceia de recebimento e confraternização

6. É essa "a novidade" da política de Getúlio que a cena analisada pretende destacar. Ela foi muito bem expressa neste testemunho do general Nélson de Melo, um opositor, antigo tenente e militar da FEB que apoiou a sua deposição em 45 e a de Jango em 64: "O operariado simpatizava com Getúlio, mas toda elite brasileira era contra ele. Eu, que peguei a época do Washington Luís, do Epitácio Pessoa, do Artur Bernardes, sei que havia uma separação incrível entre o povo e o governo. Foi Getúlio quem reconciliou o povo com o governo. O povo estava com ele; a elite, não. E, nesta hora [quando do golpe], o povo não adianta nada. Não adianta fome. Os esfaimados não depõem ninguém. Quem depõe são os de barriga cheia, os bem instalados na vida. Aqui, é a classe 
que organizaram na fazenda para o bando de Riobaldo, tiveram todos que se sentar à mesma mesa; além dos chefes jagunços, aqueles homens do fundo do sertão, Borromeu e Guirigó:

Mas não desordeei nem coagi, não dei em nenhuma desbraga. Eu não estava com gosto de aperrear ninguém. E o fazendeiro, senhor dali, de dentro saiu, veio saudar, convidar para a hospedagem, me deu grandes recebimentos. Apreciei a soberania dele, os cabelos brancos, os modos calmos. Bom homem, abalável. Para ele, por nobreza, tirei meu chapéu e conversei com pausas.

- "Amigo em paz? Meu chefe, entre, a valer: a casa velha é sua, vossa..." - ele pronunciou.

Eu disse que sim. Mas, para evitar algum acanhamento e desajeito, mais tarde, também falei: - "Dou todo respeito, meu senhor. Mas a gente vamos carecer de uns cavalos..." Assim logo eu disse, em antes de vir a amolecer as situações e estorvar o expediente negócio a boa conversação cordial.

O homen não treteou. Sem se franzir nem sorrir, me respondeu:

- "O senhor, meu chefe, requer e merece, e com gosto eu cedo... Acho que tenho para coisa de uns cinco ou sete, em estado regular."

E eu entrei com ele na casa da fazenda, para ela pedindo em voz alta a proteção de Jesus. Onde tive os usuais agrados, com regalias de comida em mesa. Sendo que galinha e carnes de porco, farofas, bons quitutes ceamos, sentados, lá na sala. Diadorim, eu, João Goanhá, Marcelino Pampa, João Concliz, Alaripe e uns outros, e o menino pretinho Guirigó mais o cego Borromeu - em cujas presenças todos achavam muita graça e recreação (Rosa, 1963, p. 426 e 427, grifos meus).

Esse encontro só aparentemente se assemelhava a um daqueles comuns entre os bandos jagunços e os seus coiteiros. Ele tem traços que

\footnotetext{
dominante quem dispõe tudo - com ou sem fome. Getúlio apodreceu no meio das elites. Mas o povo não tomou conhecimento e continuou getulista" (Lima, 1986, p. 221). Que coincide com o de um colaborador, Cleanto de Paiva Leite, da acessoria econômica de Rômulo de Almeida: "O populismo às vezes é empregado como uma maneira deliberada de enganar o povo. Eu acho que o Getúlio não queria enganar o povo, ele queria incorporar o povo às decisões do governo. Ele foi talvez o primeiro presidente, na história republicana, que teve essa visão de que a incorporação das massas ao processo político era parte do desenvolvimento nacional" (Lima, 1986, p. 260).
} 
fogem muito à tradição jagunça e coronelística. Ele é tenso e cordial, pois, ao mesmo tempo em que cada um faz do outro o "seu senhor", também não deixa de explicitar o seu interesse, "vamos carecer de uns cavalos", chega dizendo Riobaldo e entremeia a exigência com o trato cortês. Portanto, se estabelece entre eles um processo de embate polido, no qual as normas da boa-convivência nunca são ultrapassadas, os limites são testados e as posições podem variar, de modo que um sempre pode subir e o outro descer, à medida que se cede ou se avança no prélio. Pelo trato dado a Riobaldo desde o início e pela sua posição de força, ele mais sobe, e, seo Ornelas, obrigado a certas concessões, mais desce, mas nenhum se impõe ou se subordina inteiramente ao outro. Tudo se passa cavalheirescamente. Porém, a garantia da civilidade do trato era dada pela grande presença feminina; eram as mulheres que quebravam certas distâncias e, pelas suas presenças, impediam manifestações agressivas. À mesa, todos se contém, fazem concessões, sem tolherem porém de todo a naturalidade, mas todos se transformam e passam a ser outros, diferentes do que eram. Quem mais percebe isso é Riobaldo, que se comporta diante das damas, procura assuntos sérios para conversar e observa o seo Ornelas. É este quem dá a pauta do modo de ser, soberano, embora tivesse cedido ao herói a cabeceira da mesa, e o jagunço então se pergunta se "tarde seria para bem aprender". Seo Ornelas também precisa se conter, aprende a aceitar estranhos à sua mesa, como Borromeu e Guirigó, "afetava de propósito não reparar no menino". Porém, com o seu estilo, "de outras mais arredadas terras" (o Rio Grande do Sul? '), governava as pessoas e os cachorros, morigerado, até que volta a refletir sobre o sertão, "confusão em grande demasiado sossego", diz e conclui que Riobaldo lhe faz bem, pois o sertão carece dele, de "um homem forte, ambulante".

A dona fazendeira era mulher já em idade fora de galas; mas tinham três ou quatro filhas, e outras parentas, casadas ou moças, bem orvalhosas. Aquietei o susto delas, e nenhuma falta de consideração eu não proporcionei nem consenti, mesmo porque meu prazer era estar vendo senhoras e donzelas navegarem assim no meio nosso, garantidas em suas honras e prendas, e com toda cortesia social. A ceia indo principiando, somente falei também

7. Pela importância que as concepções de Oliveira Vianna têm na obra de Guimarães Rosa, seria interessante verificá-las também quanto a esse assunto. V. Vianna, 1952. 
de sérios assuntos, que eram a política e os negócios da lavoura e cria. Só faltava lá uma boa cerveja e alguém com jornal na mão, para alto se ler e a respeito disso tudo se falar.

Seo Ornelas me intimou a sentar em posição na cabeceira, para principal. - "Aqui é que se abancava Medeiro Vaz, quando passou..." - essas palavras. Medeiro Vaz tinha regido nessas terras. Verdade era? Aquele velho fazendeiro possuía tudo. Conforme jagunço de meio-ofício tinha sido, e amigo hospedador, abastado em suas propriedades. De ser de linhagem de família, ele conseguia as ponderadas maneiras, cidadão, que se representava; que, isso, ainda que eu pelejasse constante, tarde seria para bem aprender. Na verdade. Aquela hora, eu, pelo que disse, assumi incertezas. Espécie de medo? Como que o medo, então, era um sentido sorrateiro fino, que outros e outros caminhos logo tomava. Aos poucos, essas coisas tiravam minha vontade de comer farto.

- "O sertão é bom. Tudo aqui é perdido, tudo aqui é achado..." - ele seo Ornelas dizia. - "O sertão é confusão em grande demasiado sossego..."

Essa conversa até que me agradou. Mas eu dei de ombros. Para encorpar minha vantagem, às vezes eu fazia de conta que não estava ouvindo. Ou, então, rompia fala de outras diversas coisas. E joguei os ossinhos de galinha para os cachorros, que ali nas margens esperavam, perto da mesa com toda atenção. Cada cachorro sungava a cabeça, que sacudia, chega estalavam as orelhas, e aparava certeiro seu osso, bem abocava. E todos, com a maior devoção por mim, e simpatias, iam passando os ossos para eu presentear aos cachorros. Assim eu mesmo ria, assim riam todos, consentidos. O menino Guirigó comeu demais, cochilava afundado em seu lugar, despertava com as risadas. Aquele menino já tinha pedido que um dia se mandasse costurar para ele uma roupa, e prover um chapéu-de-couro para o tamanho de sua cabeça dele, que até não era pequena, e umas cartucheiras apropositadas. "Tu é existível Guirigó... Vai pelos proveitos e preceitos." - eu caçoava. Aí caçoei: - "Duvidar, é só dar um saco vastoso na mão dele, e janela para pular, para dentro e para fora: capaz de supilar os recheios e pertences todos duma casa-grande de fazenda, feito esta, salvo que seja..." E eu bem que já estava tomando afeição àquele diabrim. Pois, com o Guirigó, as senhoras e moças conversavam e brejeiravam, como que só com ele, por criança, elas perdessem o acanhamento de falar. Mas o seo Ornelas permanecia sisudo, faço que ele afetava de propósito não reparar no menino. Pelo tudo, era como se ele reprovasse minha decisão de trazer para a mesa semelhantes companhias. O menino e o cego Borromeu - aqueles olhos perguntados. - "As colheitas..." - seo Ornelas supracitava. Homem sistemático, sestronho. O moderativo de ser, o apertado ensino em doutrinar os cachorros, 
O eixo e a roda: $v .12,2006$

Disponível em: bttp://www.letras.ufmg.br/poslit

ele obrava tudo por um estilo velhoso, de outras mais arredadas terras - sei se sei. E quase não comia. Só, vem outra, jogava na boca um punhado seco de farinha.

- "Oxalá, o senhor vai, o senhor venha... O sertão carece... Isto é, um homem forte, ambulante, se carece dele. O senhor retorne, consoante que quiser, a esta casa Deus o traga..." (Rosa, 1963, p. 427 e 428, grifo meu).

A última observação de seo Ornelas, da necessidade no sertão de "um homem forte", provocou Riobaldo, que entendeu não entendendo, pois não encontrava resposta para ela, o que despertou nele instintos até então represados. O seo Ornelas deve ter percebido o que se passava com o herói, mas não adiantou depois tentar consertar, dizendo humildemente: "Pois maior honra é a minha, meu Chefe: que em posto de dono, na pobreza desta mesa, somente homens de alta valentia e valia de caráter se sentaram..." Riobaldo ficou tomado pela ferocidade e se comparou a uma mula querendo escoicear: "Dobrei, de costas, castanheteei para os cachorros. Assim ele havia de sentir o perigo de meu desprazer; havia de recear, de mim, aquilo - como o outro diz: ...quando o burro dá as ancas!..." (Rosa, 1963, p. 429). E a sua perda de autodomínio não parou aí; quando percebeu os olhos de Diadorim e viu que o vigiava, ele voltou-se para uma das mocinhas de lá, "a mais vistosa de todas". Era uma neta de seo Ornelas, e é muito interessante a descrição sintética que Riobaldo faz dela, vestida com as cores da bandeira do Estado de São Paulo: "A mocinha essa de saia preta e blusinha branca, um lenço vermelho na cabeça - que para mim é a forma mais assentante de uma mulher se trajar." Por coincidência ou não, Ivete Vargas, a sobrinha-neta de Getúlio que mais se sobressaiu na política, fincou a sua base justamente nesse Estado, onde foi uma das líderanças mais destacadas do PTB, partido pelo qual foi deputada por longos anos. Embora essas identificações não sejam vitais para a compreensão do romance, não deixam de nos surpreender como o autor se serviu da matéria prosaica para as suas altas elaborações. Ou, de modo mais elucidativo, como as suas representações só se revelam em toda complexidade de significações, quando, pelas informações externas, conseguimos desvendar que os materiais que lhes dão corpo e sustentação não são arbitrários e caprichosos.

Os mesmos freios civilizatórios que ele tendia a perder com seo Ornelas, ele se inclinava também a perder com a neta, o que deixava o velho fazendeiro apreensivo, como se estivesse ocorrendo ali uma atração perigosa (como sempre acontece, para o pensamento conservador das elites, quando vê 
o povo se assenhorar do poder). Nesse momento, de fato a violência eclode na cabeça do herói: ele se vê matando o velho com um tiro entre os olhos; Diadorim dominado pelos seus comparsas; e ele se apossando da mocinha, que esperneava, "eu agarrava nos braços". Porém, ele se contém, como se conteve também quando cobiçou a mulher do Hermógenes ao aprisioná-la, embora por outras razões: "Tive um receio de vir a gostar dela como fêmea. Meio receei ter um escrúpulo de pena; certo não temi abrir razão de praga" (Rosa, 1963, p. 486). Como a praga que a última moça estuprada por ele lhe rogou. O que o contém agora, ao contrário, não é o temor de praga, mas uma grande iluminação. Ele diz, "uma razão maior - que é o sutil estatuto do homem valente", quando percebe que a sua força tanto poderia servir para ameaçar como para proteger, "eu gostava de dar a ela muito forte proteção". O que ocorre para ele é uma espécie de reconhecimento de que se precisava de mais valentia para conter a violência do que para exercê-la. Foi este último sentimento que imperou nele, o gozo do uso da força para proteger e impedir a violência. É muito sugestivo acompanhar a sua decisão e o modo fortemente expressivo que usa para descrevêla, como uma vontade que o fez se superar e se tornar quase um outro:

Mas eu não quis! Ah, há-de-o, quanto e qual não quis, digo ao senhor. e Deus mesmo baixa a cabeça que sim: ah, era um homem danado diverso, era, eu - aquele jagunço Riobaldo... Donde o que eu quis foi oferecer garantia a ela, por sempre. Ao que debati, no ar, os altos da cabeça. Segurei meus cornos. Assim retido, sosseguei - e melhor. Como que, depois do fogo de ferver, no azeite em corpo de meu sangue todo, agora sochupei aquele vapor fresco, fortíssimo, de vantagens de bondades (Rosa, 1963, p. 430 e 431, grifos meus).

Essa decisão e a forma nova de usar o poder o colocam no lugar do outro, de alguém capaz de apadrinhar, ele que até então só tinha sido apadrinhado. Para quem conhece a vida social brasileira, sabe como essa mudança, da dependência de padrinho para a própria existência ao poder de apadrinhar, equivale à passagem de uma extremidade da sociedade à outra.

8. O que é interessante notar, é que essa dinâmica social, tal como está representada nessa cena, apenas possibilitava a inversão das posições, de modo que um viesse a ocupar o lugar do outro, porém não modificava o todo social ao ponto de permitir um certo nivelamento e, com isso, pudessem todos prescindir da instituição do apadrinhamento. 
Isso o faz exultar e declarar, como alguém capaz de estender a ordem familiar e civilizatória pelo sertão e de ser o seu fiador:

- "Menina, tu há de ter noivo correto, bem apessoado e trabalhador, quando for hora, conforme tu merece e eu rendo praça, que votos faço... Não vou estar por aqui, no dia, para festejar. Mas, em todo tempo, vocês, carecendo, podem mandar chamar minha proteção, que está prometida - igual e fosse padrinho legítimo em bodas!" (Rosa, 1963, p. 430 e 431).

Não foi à toa que depois do alívio e regozijo geral com a sua atitude, numa conversa de varanda com o seo Ornelas, "homem dos sertões transatos", sertões que se viam também suprimidos pela sua sensatez, entre assuntos de jagunçagem e antigas chefias, o fazendeiro lhe contou um caso que presenciara na Januária, com o delegado Dr. Hilário, "rapaz instruído social, de muita civilidade". O causo é bastante comentado pela crítica; foi uma brincadeira feita pelo Dr. Hilário, quando, numa roda de conversa, chegou um capiau carregando a trouxa na ponta de um pau e perguntou pelo delegado, e este lhe disse que era um outro moço que estava ali ao lado, um tal de Aduarte Antoniano. Foi o que bastou para que o capiau desvencilhasse o pau da trouxa e com ele quebrasse a cabeça do Aduarte. Quando o Dr. Hilário, moço apreciador de exemplos, lhe disse, comentando o fato, "- Pouco se vive, e muito se vê...", o seo Ornelas lhe perguntou qual era o mote. O delegado então lhe disse, e era um dito moral que explicitava justamente as posições diferentes nas quais o fazendeiro e o herói se encontravam, além de explicar porque o delegado podia ser considerado instruído, quer dizer, não se deixar nunca passar pelo que não era, algo como o que estava fazendo Riobaldo: "- Um outro pode ser a gente; mas a gente não pode ser um outro, nem convém... - o dr. Hilário completou. Acho que esta foi uma das passagens mais instrutivas e divertidas que em até hoje eu presenciei..." (Rosa, 1963, p. 433).

Aqui termina o flashback e retornamos à segunda chegada de Riobaldo à Barbaranha, só que agora não mais como chefe de grande bando e numa posição de força. Ele chega saído daquela grande febre e debilitado. É seo Ornelas que o socorre, com as suas mulheres e cordialidade, e lhe dá toda proteção, "fui príncipe naquela casa". E é aí que ocorrem os dois fatos mais decisivos do destino do herói, que lhe definem o futuro e o integram numa ordem pacífica e civil, sob o patrocínio de seo Ornelas, como uma compensação ao apadrinhamento e proteção que o herói havia prometido anteriormente a 
sua neta. O primeiro, foi a chegada na Barbaralha, onde o herói repousava, de Otacília com a mãe, parentes e comitiva. Ao recebê-la, Riobaldo não lhe esconde o passado, fala do amor perdido e da necessidade de um tempo de luto; Otacília, cordata, compreende e aceita; porém fica prometido o enlace com todas as festas e rituais das bodas legais, o que ocorre "quando deu o verde nos campos", numa primavera de regeneração. O segundo, foi a chegada na mesma Barbaranha do seo Habão, reconciliado agora com seo Ornelas, como o homem do capital comercial repactuado com o fazendeiro sesmeiro de linhagem e tradição (como havia ocorrido após a Revolução de 30, nos governos de Getúlio Vargas, a aliança do capital agrário exportador com o urbano industrial). Ele vinha para comunicar a Riobaldo a morte do padrinho, Selorico Mendes, e a herança com que o tinha abençoado e honrado: "as duas maiores fazendas ele tinha deixado para mim, em cédula de testamento" (Rosa, 1963, p. 567 e 568). Depois da promessa de integração familiar, ele recebia agora a de integração proprietária, como fazendeiro e homem de posses, o que concretizaria em definitivo a sua mudança de condição e de classe. Era o final da metamorfose da lagarta Tatarana, num fazendeiro domesticado, "quase barranqueiro", sob o patrocínio de seo Ornelas/Getúlio Vargas. Mas, como o casamento, ele também adiava a posse das fazendas para depois do luto e do reconhecimento do seu passado, o que irá fazer no lugar selvagem da deusa selvagem, Os-Porcos, onde irá inquirir sobre quem foi a sua Ártemis/Diadorim.

Como conclusão provisória - se estou certo e não vi apenas fantasmas no Grande Sertão: Veredas -, acho que a partir da distinção feita pelo autor quanto ao valor dos dois eventos e das duas personagens históricas, do que uma continha de regressivo e passadismo e a outra de modernizante e promessa de futuro, creio que se fortalece a camada histórico-alegórica do romance e ele tem de ser lido de um modo um tanto diverso do que tem sido até agora.

Em 24 de agosto de 1954, Getúlio Vargas, presidente democraticamente eleito do Brasil, suicidou. O ineditismo não estava no fato disso ter acontecido pela primeira vez na vida política do país, mas no seu aspecto trágico, numa esfera que tinha sido sempre representada como a da comédia: nela, a mudança havia sido figurada mais com a cara da graça humorística do com a do terror jacobino. Quem leu Esaú e Jacó, de Machado de Assis, viu a melhor representação crítica disso. Nessa esfera, tudo acabava sempre em acomodação, conciliação e soluções de compromissos, por isso o 
drama só poderia ser entendido no plano de um mito do eterno retorno ou repetição e não no da história e da mudança. Agora não, um homem sacrificava a própria vida, como o último recurso, para dar ao gesto uma dimensão política e afirmar na última carta as próprias convicções. Este sacrifício do pessoal ao público de modo tão incisivo era uma coisa inédita e destoava da nossa tradição. O que o ato significou, pode ser bem percebido na palinódia de um dos seus algozes mais "civilizados" e "liberais" da UDN, Afonso Arinos de Mello Franco. Porém, ele foi sincero bastante para reconhecer a ânsia parricida e cruel que movia as nossas elites:

Foi um drama. A crise virou drama pessoal e o drama pessoal transformouse em drama nacional. Para mim aquilo também foi um trauma, porque de repente eu senti a participação que nós tínhamos tido naquele episódio todo. Quando eu soube da morte dele, tive um sentimento de filho e pensei no meu pai. Eu me lembrei dos filhos dele, era só essa idéia que eu tinha. Ele ficou acuado como um cão dentro daquele palácio, os lobos atacando, atacando, e ele fugindo, fugindo, até acabar fechado dentro de um quarto e se matar, e não ter ninguém para atender. Isso me desgostou, me deu um enjôo, não sei, é muito difícil... (Lima, 1986, p. 267).

Apesar do remorso, os mesmos guardiões da moral da cidade continuaram apelando para as Fúrias contra outros e outros e outros presidentes eleitos. Nesse mesmo ano, numa entrevista à revista Visão, de 23 de julho, portanto, um mês antes da tragédia, João Guimarães Rosa anunciou os seus dois livros: Corpo de Baile e Veredas Mortas (o primeiro título do Grande Sertão, que saiu publicado só dois anos depois, tempo suficiente para alterações como a do título). Uma coisa podia não ter nada a ver com a outra, mas, para quem não secciona e isola o autor de seu tempo e dos eventos vividos, o lugar que seo Ornelas, o fazendeiro das Veredas Altas, ocupa no romance, sugere a possibilidade de haver aí certo reconhecimento e certa homenagem, sem deixar de levantar-nos a pergunta, se eles não teriam também contribuído para a mudança do título do romance. 
Abstract: The purpose of this study was trying to detach from the representations of Antônio Conselheiro and Getulio Vargas, two of the more singular figures of our history, which I was fortunate finding and identifying in another work about "Grande Sertão: Veredas", Guimarães Rosa's view and the judgment about them. It was possible to apprehend this from the analysis of the significations that they acquired in the book and of the importance that they had for the definition of hero Riobaldo's, narrator of the romance "Grande sertão: veredas", destiny.

Key words: representation, literature, history and politics.

\section{Referências Bibliográficas}

ARINOS, A. Os Jagunços. 3. ed. Rio de Janeiro: Philobiblion/Pró-memória/INL, 1985.

ASSIS, M. Obra Completa. Rio de Janeiro: José Aguilar Editora, 1973. V. III.

CAMARGO, A.; ARAÚJO, J. H. P. de; SIMONSEN, M. H. Oswaldo Aranha: a Estrela da Revolução. São Paulo: Editora Mandarim, 1996.

CUNHA, E. Os Sertões. Edição crítica de Walnice Nogueira Galvão. São Paulo: Editora Brasiliense, 1985.

FONTOURA, J. N. da. Memórias. A Aliança Liberal e a Revolução de 30. Rio de Janeiro/ Porto Alegre/São Paulo: Editora Globo, 1963. V. 2.

GRAHAM, R.B.C.. Um Místico Brasileiro. Trad. Gênese Andrade e Marcela A. C. Silvestre. São Paulo: Sá Editora/Editora UNESP, 2002.

LIMA, V. da R. Getúlio: uma história oral. Rio de Janeiro: Editora Record, 1986.

RONCARI, L. O Brasil de Rosa. O amore o poder. São Paulo: Editora UNESP / FAPESP, 2004.

RONCARI, L. O Cão do Sertão. São Paulo: Editora UNESP, 2006. (prelo)

ROSA, J.G. Grande Sertão: Veredas. Rio de Janeiro: José Olympio, 1963.

ROSA, V. G. Relembramentos: João Guimarães Rosa, meu pai. Rio de Janeiro: Editora Nova Fronteira, 1983.

VARGAS, G. Diário. Volume I. Edição de Leda Soares. São Paulo/Rio de Janeiro: Siciliano/ FGV Editora, 1995.

VIANNA, O. Populações Meridionais do Brasil. Segundo Volume (póstumo). Rio de Janeiro: José Olympio, 1952. 